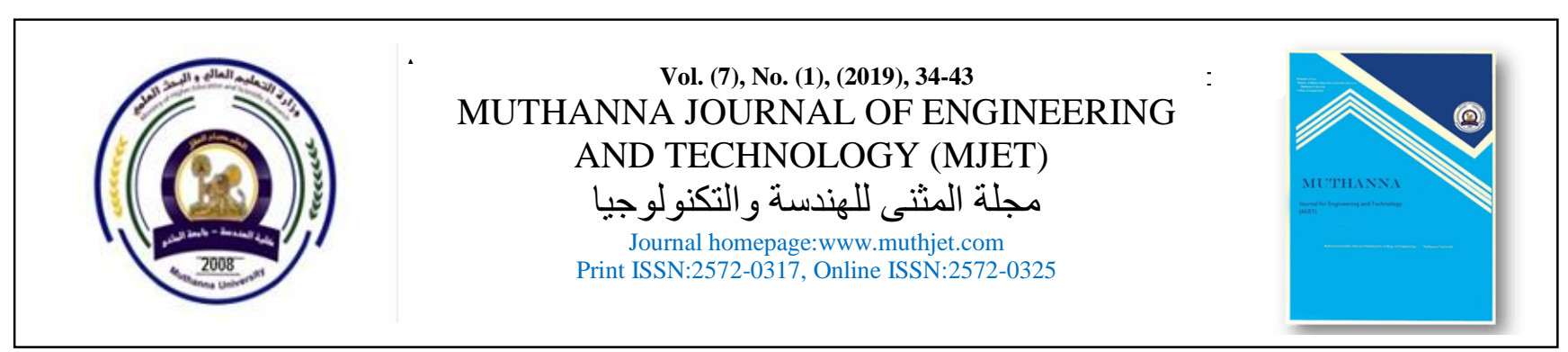

\title{
Influence of PVC Fiber Reinforcement on Shear Strength in Concrete Beams
}

Kadhim Zuboon Nasser ${ }^{a}$, Ali Abdulhasan Khalaf ${ }^{\text {a }}$, and Fadhil Kamil Idan ${ }^{a}$

a Civil Engineering Department, College of Engineering, university of Basrah, Iraq

\section{ARTICLE INFO}

Received: 29/05/2019

Accepted:01/09/2019

\begin{tabular}{l}
\hline Keywords \\
\hline PVC fiber, Shear \\
Reinforcement, Corrosion, \\
Crack load, Ultimate load, \\
Crack width
\end{tabular}

\begin{abstract}
ABSTRA CT
This study adopted the investigation of the effect of a material that can be used as an alternative to steel reinforcement of shear in reinforced concrete beams, as the most susceptible to corrosion to which reduces the time service of the concrete structures and increase the maintenance costs is the steel reinforcement of shear for the closeness of surface of concrete. Therefor non-corroding material is needful for concrete structures and PVC fiber reinforcement is chosen. Experimentally nine reinforced concrete beams have been tested to determine the effect of PVC fiber reinforcement on the concrete beam resistance load, the load of cracks, deflection achieved and distribution with dimension of cracks. Three volume fraction ratios were taken for PVC fiber reinforcement $(0,0.25$ and 0.5), which were identical to the shear reinforcement used in this research (0,0.29 and 0.54). All the concrete beams were tested with in on one program by applied a center load from the top in the middle to the failure load and the results were impressive. The specimens containing the PVC fiber reinforcement percentages achieved a remarkable increase in the crack and ultimate load of the concrete beams before and after cracks with direct effect in changing the failure type. While the deflection achieved due to the increase in PVC fiber percentage is more than the allowable deflection in the ACI Code equations of the reinforced concrete beams and more of these if the use of PVC fiber and steel reinforcement of shear together. A smaller measurement of the maximum cracks width was achieved by using advanced percentages of PVC fiber and shear reinforcement $(0.5$ and 0.54$)$ respectively.
\end{abstract}

*Corresponding author:

E-mail addresses: Kadhimzuboon@gmail.com C2019AL-Muthanna University. All rights reserved. DOI: $10.52113 / 3 / \mathrm{mjet} / 2019-7-1 / 34-43$ 


\section{Introduction.}

In a century, there are many changes and rapid movement to enhance durability and sustainability of reinforced concrete structures. Commonly, reinforced concrete is a mix of cement, aggregate, water, steel reinforcement, and additives. These materials have some disadvantages. One of the most important problems is that steel reinforcement of shear susceptible to rust which increase the cost of maintenance because steel shear reinforcement is the nearest to the surface of concrete. In this case, it will suffer corrosion and cause a shortage of life of the concrete structures. The new challenge in researches is to identify alternative methods of traditional steel shear reinforcement $[1,2]$. One effective technique through which the shortage can be compensated by non-use of steel reinforcement of shear is reinforcing concrete by fibers. A random distribution for extended fibers works as a bridge carrying the produced stresses when shear load imposed on concrete structures [3, 4].Many experimental studies have been conducted to predict shear strength of reinforced concrete beams with fibers as an additional reinforcement for steel shear reinforcement or alternative. [5,6,7] they studied the shear strength for steel fibers reinforced concrete beams with and without stirrups, they have studied the effect of volume change percent of fibers (1\% and 2\%).\%). [8,9] also the fibers reinforcement used to developed the Ultra-high performance concrete which formed what is known as abbreviation (UHPFRC) and must parameter was study the fiber reinforcement volume. However, the concentration of these studies was on use of steel fiber which gave a distinctive results in increasing the shear strength and enhancement of durability of concrete beams while the main problem still exists, the corrosion of steel fiber with increased vicinity to the surface of concrete. Therefore, a solution can be found for the sum of the facts by using PVC fiber reinforcement .PVC fiber reinforcement was used timidly and very little increasing of concrete ultimate load and shear strength in previous researches and was focused on controlling plastic shrinkage cracks in concrete $[10,11,12]$.

This experimental investigation aims to provide non-corrosion material. It is the PVC fiber for using as an additional and alternative for steel reinforcement of shear. The experimental program is leading to analyze the influence of using different volumetric percentages of such material on shear strength, crack patterns and crack mood in reinforced concrete beams by using local materials.

\section{Experimental test program.}

\section{2-1 Tools of Testing:}

1- A mechanical mixer of $1 / 2$ bag of cement capacity is used to mix the concrete components.

2-Universal Compressive Instrument, Torsee's, is used to impose the loading. It has a capacity of 200 ton.

3- Dial gauge with $0.001 \mathrm{~mm}$ accuracy is used.

4- Crack detection microscope with accuracy of $2.00 \mathrm{~mm}$.

\section{2-2 Samples}

The experimental test program contained nine rectangular reinforced concrete beams. All beam specimens have $1200 \mathrm{~mm}, 150 \mathrm{~mm}$ and $300 \mathrm{~mm}$ total length, width and height, respectively. Four longitudinal reinforcement deformed bars with diameter of $12 \mathrm{~mm}$ are used in all the beam specimens. The main variables are the percentage of steel reinforcement of shear $\left(\rho_{\mathrm{s}}\right)$ percentage and the quantity of PVC fibers. The steel shear reinforcement is used in three percentages $(0,0.27$ and 0.54$)$. Fig.(1) shows the formwork and rebar fabrication and distribution which are used in the tested beam specimens. The steel reinforcement of shear bars are used with diameter of $6 \mathrm{~mm}$. Both shear and bending reinforcement bars were laced and tied together by using $(0.2 \mathrm{~mm})$ steel wire .The designation label is used for the PVC fiber-reinforced concrete beam : B X-Y, where $\mathrm{X}$ is the PVC fiber volume portion percentage, $\mathrm{Y}$ refers to percentage of shear reinforcement. Table No. (1) shows the details of both reinforcing methods of beams used in the experimental test program.

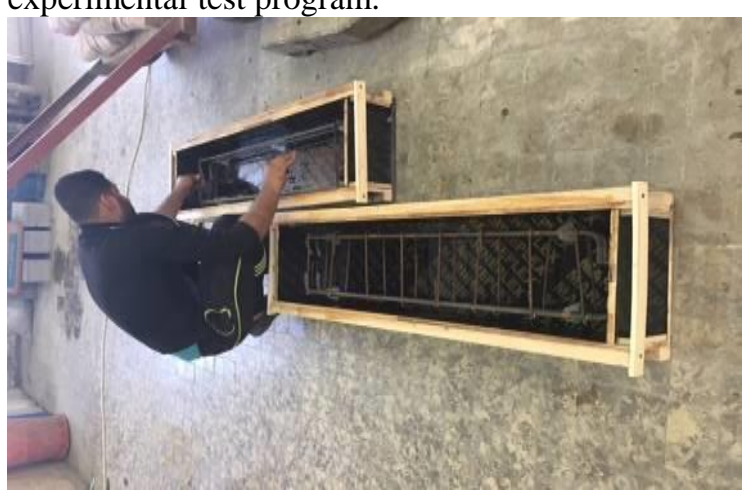

Fig.(1) Show the wooden and rebar fabrication used in testing concrete beams. 


\begin{tabular}{cccccc}
\hline $\begin{array}{c}\text { Beam } \\
\text { definition }\end{array}$ & $\begin{array}{c}\text { PVC fiber } \\
\text { percentage } \\
\text { Vf }(\%)\end{array}$ & $\begin{array}{c}\text { steel } \\
\text { reinforcement of } \\
\text { shear } \rho \text { s(\%) } \\
\text { percentage }\end{array}$ & $\begin{array}{c}\text { Beam } \\
\text { definition }\end{array}$ & $\begin{array}{c}\text { PVC fiber } \\
\text { percentage } \\
\text { Vf }(\%)\end{array}$ & $\begin{array}{c}\text { steel } \\
\text { reinforcement of } \\
\text { shear } \rho s(\%) \\
\text { percentage }\end{array}$ \\
\hline B-0-0 & 0 & 0 & B-0.5-0.29 & 0.5 & 0.29 \\
B-0.25-0 & 0.25 & 0 & B-0-0.54 & 0 & 0.54 \\
B-0.5-0 & 0.5 & 0 & B-0.25-0.54 & 0.25 & 0.54 \\
B-0-0.29 & 0 & 0.29 & B-0.5-0.54 & 0.5 & 0.54 \\
B-0.25-0.29 & 0.25 & 0.29 & & & \\
\hline
\end{tabular}

Table No. (1) the details of both reinforcing methods of beams used in the experimental test program.

\section{Mixture proportion and mixing.}

One proportion of concrete mixtures is used for all concrete beams specimens .It is 1:1.5:3 (cement, sand and gravel). The watercement ratio is $0.45 \%$ of the weight of cement with super plasticizer of $0.55 \%$ of weight of cement. After cleaning and moisturizing the inner side of mixer, the materials are placed. At first, the fine (sand) and coarse (gravel) aggregate are batched into the mixer and mixed before batching the cement . These three components are mixed for 10 minuts. The super plasticizer is added to the water, and then water poured into the mixer. The mixing process continues until producing the homogenous mixture. PVC fiber reinforcement is added to the mixtures as defined in Table (1). This process is done by manual spraying .Fig.(2) exhibits preparing and adding of PVC fiber. The mixing of fresh concrete is continued until getting a homogenous distribution for PVC fibers. Wooden molds are used for placing and forming the concrete beams. The molds have been cleaned and oiled before pouring the fresh concrete. In addition, the electrical vibrator has been used to compact and consolidate the fresh concrete.

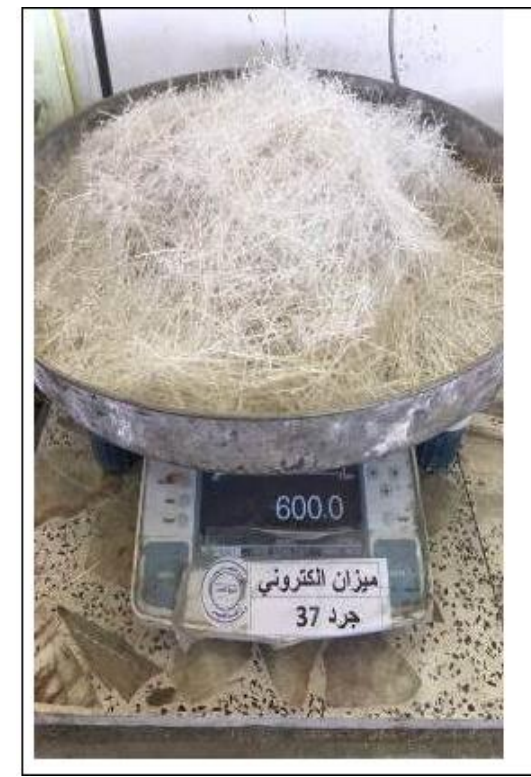

(a) Preparing the PVC fibers

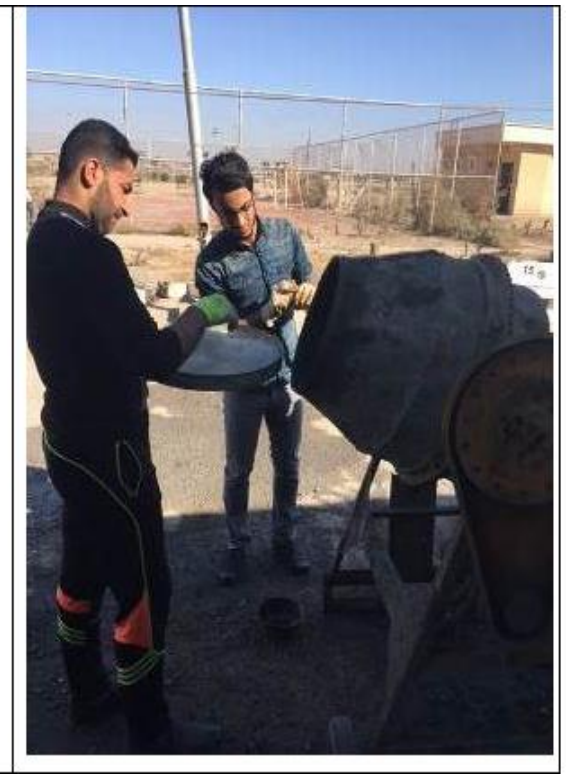

(b) Hand spraying the PVC fibers

Fig.(2) Shows a- Preparing the PVC fibers b- Hand spraying the PVC fiber.

\section{Characteristics of mixture materials.}

4-1- Cement: The locally manufactured cement type "I", ordinary Portland cement, is used in this project. Table (2) shows cement properties. 


\begin{tabular}{|c|c|c|}
\hline \multicolumn{2}{|l|}{ Chemical } & Limits \\
\hline $\mathrm{SiO} 2$ & 22.1 & - \\
\hline AL2O3 & 5.0 & - \\
\hline $\mathrm{CaO}$ & 60.5 & - \\
\hline $\mathrm{Fe} 2 \mathrm{O} 3$ & 3.1 & - \\
\hline $\mathrm{MgO}$ & 2.35 & $<\varepsilon$ \\
\hline $\mathrm{SO} 3$ & 2.28 & $<r$ \\
\hline Alkalis & 0.8 & \\
\hline Loss on ignation & 2.5 & $<4$ \\
\hline Insolube residue & 0.8 & $1.5<$ \\
\hline \multicolumn{3}{|l|}{ Potential Compound } \\
\hline $\mathrm{C} 3 \mathrm{~S}$ & 48 & $42-67$ \\
\hline $\mathrm{C} 2 \mathrm{~S}$ & 25 & $8-31$ \\
\hline $\mathrm{C} 3 \mathrm{~A}$ & 9 & $6-12$ \\
\hline $\mathrm{C} 4 \mathrm{AF}$ & 12 & $5-14$ \\
\hline L.S.F & 0.84 & $0.66-1.02$ \\
\hline \multicolumn{3}{|l|}{ Physical } \\
\hline $\begin{array}{c}\text { Setting Time: } \\
\text {-Initial setting time: }\end{array}$ & 84 minutes & $\begin{array}{l}\text { More than } \\
60 \text { minutes }\end{array}$ \\
\hline -Final setting time: & $\begin{array}{l}350 \\
\text { minutes }\end{array}$ & $\begin{array}{l}\text { Less than } \\
600 \text { minutes }\end{array}$ \\
\hline $\begin{array}{l}\text { Fineness: } \\
\text {-Retained on sieve } \\
\text { No. } 170(90 \mu \mathrm{m})\end{array}$ & $7.4 \%$ & $\begin{array}{l}\text { Less than } \\
10 \%\end{array}$ \\
\hline $\begin{array}{l}\text { Compressive Strength } \\
\text { (mortar) }-3 \text { days }\end{array}$ & $15.9 \mathrm{MPa}$ & $\begin{array}{l}\text { More than } \\
15 \mathrm{~N} / \mathrm{mm} 2\end{array}$ \\
\hline $\begin{array}{l}\text { Compressive Strength } \\
\text { (mortar) -7 days }\end{array}$ & $24.3 \mathrm{MPa}$ & $\begin{array}{l}\text { More than } \\
23 \mathrm{~N} / \mathrm{mm} 2\end{array}$ \\
\hline
\end{tabular}

Table (2) . Cement Properties.

4-2 Aggregate: Fine and coarse aggregate is supplied from local sources brought from Suffan, south of Iraq. The maximum sizes for fine and coarse aggregate are $4 \mathrm{~mm}$ and 12.5 $\mathrm{mm}$ respectively. Figure (3) represents grading of fine and coarse aggregate.

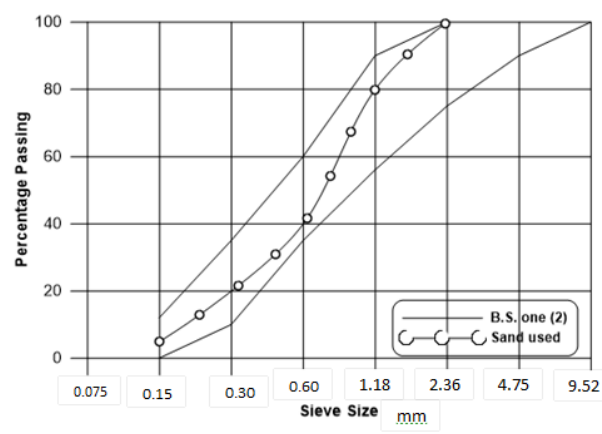

a- Grading of Fine Aggregate.

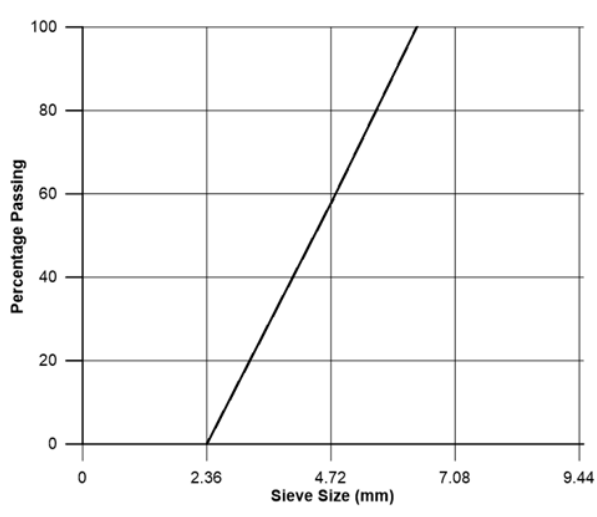

b- Grading of Course Aggregate.

Fig.(3). Grading of Fine and Course Aggregate.

4-3 Water: R.O "reverse osmosis" water is used in this research. It is treated in a location close to the place of research site. 4-4 Super plasticizer: it is third generation super plasticizer for high early strength for concrete and manufactured according to ASTM-C-494TypeE.

4-5 Steel reinforcement: The longitudinal steel reinforcement of all the beam specimens is constant with a total number of 4 bars and a diameter of $12.5 \mathrm{~mm}$ while its yield strength is $420 \mathrm{Mpa}$. Both the steel reinforcement of shear and the PVC fibers reinforcement are the main variables. In this research, steel shear reinforcement percentages of $(0,0.29$ and $0.54)$ are used as defined in the experimental test program earlier. A $6 \mathrm{~mm}$ diameter is used in shear reinforcement and its yield strength is $420 \mathrm{MPa}$.

4-6 PVC fiber reinforcement: There are three volumetric percentages of PVC fibers reinforcement used in this project for each of three concrete beam specimens having the same steel reinforcement of shear value. These are $(0,0.25$ and 0.5$)$. The length and diameter of PVCE fiber reinforcement are $50 \mathrm{~mm}$ and $0.3 \mathrm{~mm}$ respectively with specific gravity of (0.91) and its tensile strength (275Mpa).

\section{Testing procedure:}

The test method for all samples prepared for this research is the same. One span beam is considered. The restrains of the samples at both ends are pin supports that provide vertical and horizontal movement restrictions. The load was applied as a single concentrated load on the span center which has achieved a shear span to depth ratio $(\mathrm{a} / \mathrm{d})$ equals to 1.5 on the both sides of the load. The load was gradually increased with recording results for deflections and stresses for each $5 \mathrm{KN}$ increment. The loading rate continued until reaching cracking load and load of failure. The measurement of the crack size was implemented when cracks 
start noticed and continued until the loading is finished. As for the distribution of Demec gauges to achieve a wider area for the purpose of studying, the stresses have been measured at 28 points including 12 points in the middle of each one of the concrete beam specimens under the line of applied load, and the rest points are distributed on the areas that are expected to undergo a significant-stress change. The distribution of Demec gauges were on the same line between the applied load

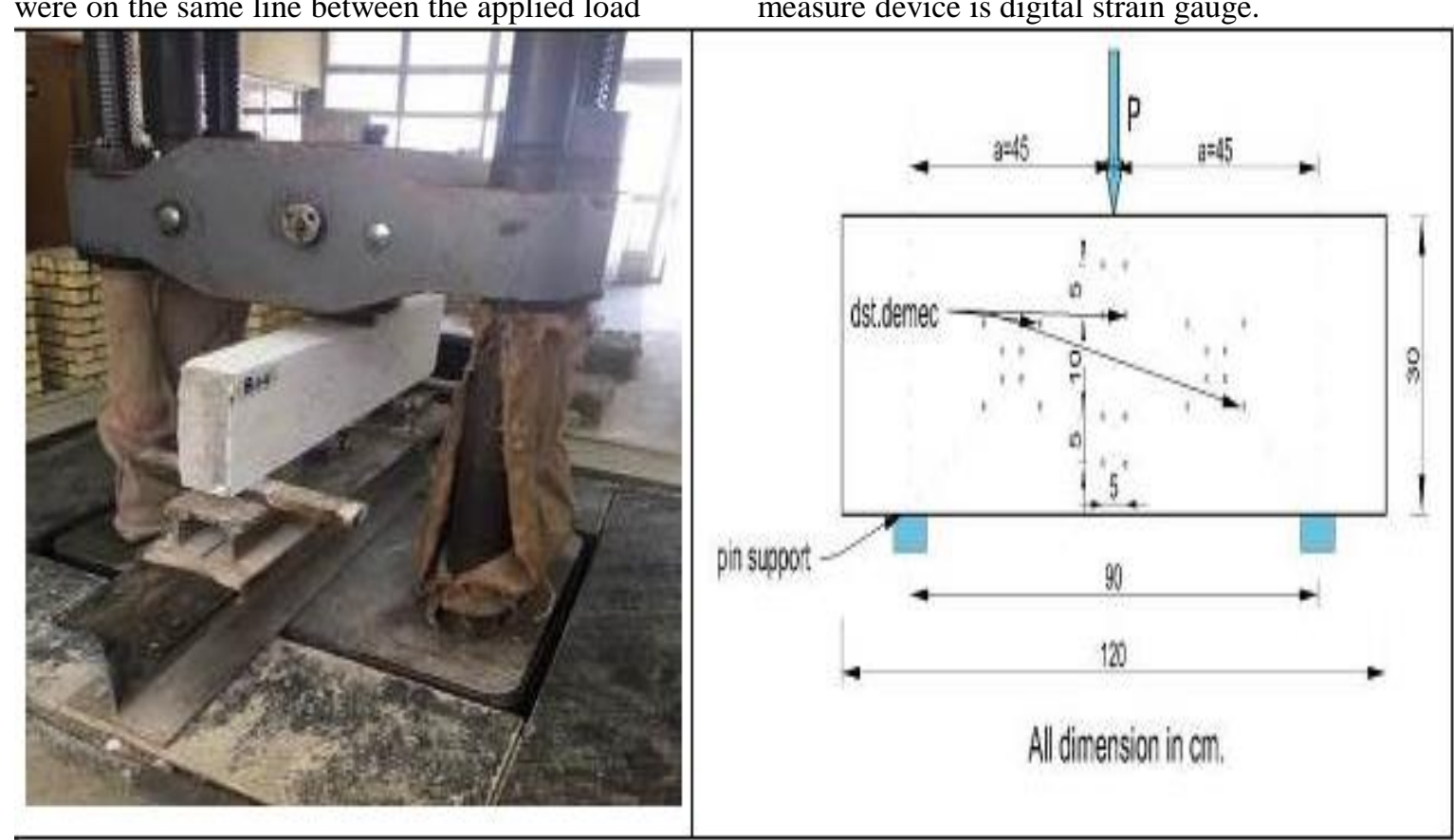

Fig.(4) Details of the shape of the concrete beam specimen are ready for test. point and support points. The second line was vertically distributed on the first line. The details of the shape of each concrete beam specimen that is equipped for test is shown in Fig.(4). The deflection was calculated by using dial gauge with accuracy $(1 / 1000) \mathrm{mm}$ fixed at the bottom of the concrete beam specimen . The readings of cracks were calculated by crack detection microscope with accuracy of $2.00 \mathrm{~mm}$ no error record, and the strain measure device is digital strain gauge.

\section{Experimental Results and Discussion.}

\subsection{Loads obtained from inspection of}

\section{concrete beam specimens.}

Both cracking load (Pcr) and ultimate load $\mathrm{Pu}$ ) were recorded during the experimental test of samples prepared for this research. The cracking load, Pcr, was recorded at the beginning of any crack appearance in concrete beam specimen surface. The obtained results were normal in terms of increasing of cracking load as a result of availability and increasing the shear steel reinforcement. However, the significant event was that the increase was greater with the availability and increase the PVC fiber reinforcement percentage. The higher values of cracking load were recorded for the samples that have a higher percentage of PVC fiber reinforcement than those which only have steel shear reinforcement. Table (3) shows the cracking load (Pcr) and ultimate load $(\mathrm{Pu})$ results. The results are labeled according to the PVC fiber reinforcement ratios.

The ratio of the increase in cracking load (Pcr) has been obtained at 27.4 $\mathrm{KN}$ and $45.0 \mathrm{KN}$ for samples B-0.24-0 and B-0.5-0 respectively and compared with sample B-0-0. On the other hand, obtaining the increase ratio of $48.3 \mathrm{KN}$ and 68.3 KN for samples B-0.25-0.29 and B0.5-0.29 respectively and compared with specimen B-0-0.29. Moreover, the values of increase ratio have been obtained for samples B-0.25-0.54 and B-0.5-0.54 of 38.0 KN and $57.7 \mathrm{KN}$ respectively and compared with sample B-0-0.54.

Thus, it is noticed that the effect of the presence and increase of PVC fiber reinforcement is a key factor to increase the cracking load (Pcr). This does not confirm exactly with what was mentioned in some 
previous researches which used the steel fiber reinforcement." The quantity of fiber only marginally affected the shear cracking load Pcr but had a significant influence on the ratio of crack growth" [13]. As for the presence of PVC fiber reinforcement and the impact on the growth of cracks during the loading, it was found matched results of previous researches. Where the PVC fiber reinforcement works as connecting bridges, it will reduce and delay the occurrence of cracks during the increase of loading and continue to extent ultimate load $\mathrm{Pu})$ at failure. Here, it can be observed from Table.(3) that the ultimate loads for concrete beam specimens remarkably increase with the availability and increasing the percentage of PVC fiber reinforcement compared with

\begin{tabular}{|c|c|c|c|c|c|}
\hline $\begin{array}{c}\text { Beam } \\
\text { Specimen }\end{array}$ & $\operatorname{Pcr}(\mathrm{KN})$ & $\begin{array}{l}\text { Percentage } \\
\text { increasing }\end{array}$ & $\mathrm{Pu}(\mathrm{KN})$ & $\begin{array}{l}\text { Percentage } \\
\text { increasing }\end{array}$ & $\begin{array}{c}\text { Shear steel } \\
\text { reinforcement } \\
\text { percentage }\end{array}$ \\
\hline B-0-0 & 51 & $\ldots \ldots \ldots$ & 98 & $\ldots \ldots \ldots$ & \\
\hline B- $0.25-0$ & 65 & 27.4 & 132 & 34.6 & 0 \\
\hline B- $0.5-0$ & 74 & 45 & 151 & 54 & \\
\hline B-0-0.29 & 60 & $\ldots \ldots \ldots$ & 121 & $\ldots \ldots \ldots$ & \\
\hline B- $0.25-0.29$ & 89 & 48.3 & 201 & 66.1 & 0.29 \\
\hline B- $0.5-0.29$ & 101 & 68.3 & 225 & 85.9 & \\
\hline B-0 -0.54 & 71 & ........ & 130 & ........ & \\
\hline B-0.25-0.54 & 98 & 38 & 212 & 63 & 0.54 \\
\hline B- $0.5-0.54$ & 112 & 57.7 & 243 & 86.9 & \\
\hline
\end{tabular}

Table. 3 exhibits the cracking load Pcr and ultimate load Pu results.

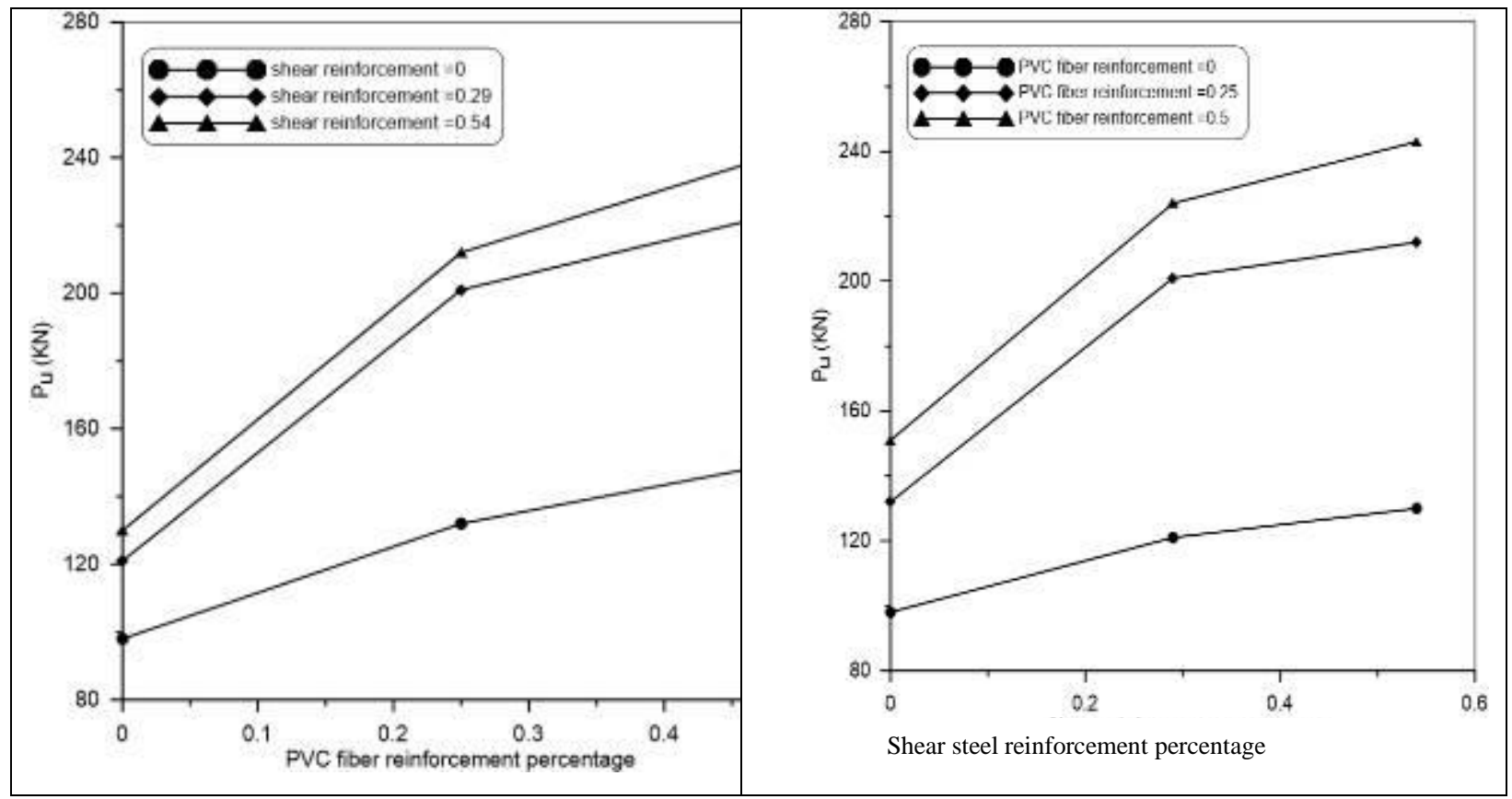

Fig.(5). Ultimate load Pu compared with PVC fiber reinforcement and Shear steel reinforcement percentage. 


\subsection{The trend of load deflection.}

The increase loading capacity and net deflection change in the middle span of samples prepared for this research and showed in Fig.(6). It can be seen that the presence and increasing the PVC fiber reinforcement in samples assist increasing the stiffness of the specimens and the maximum load resistance practically in the first loading stages (elastic region).That is achieved when adding the PVC fiber reinforcement that is equal or slightly lower than the impact of shear steel reinforcement as shown in the samples of groups (B) and (C) which are stiffer than the samples of group (A) in plastic stage . However, there is a substantial difference between the samples containing the PVC fiber reinforcement and those with shear steel reinforcement in the ductility and the load resistance. According to Fig(6), it can be noticed that the samples containing the PVC fiber reinforcement give a significant drop in the net deflection at the cracking loads which is much less than the amount in group A.

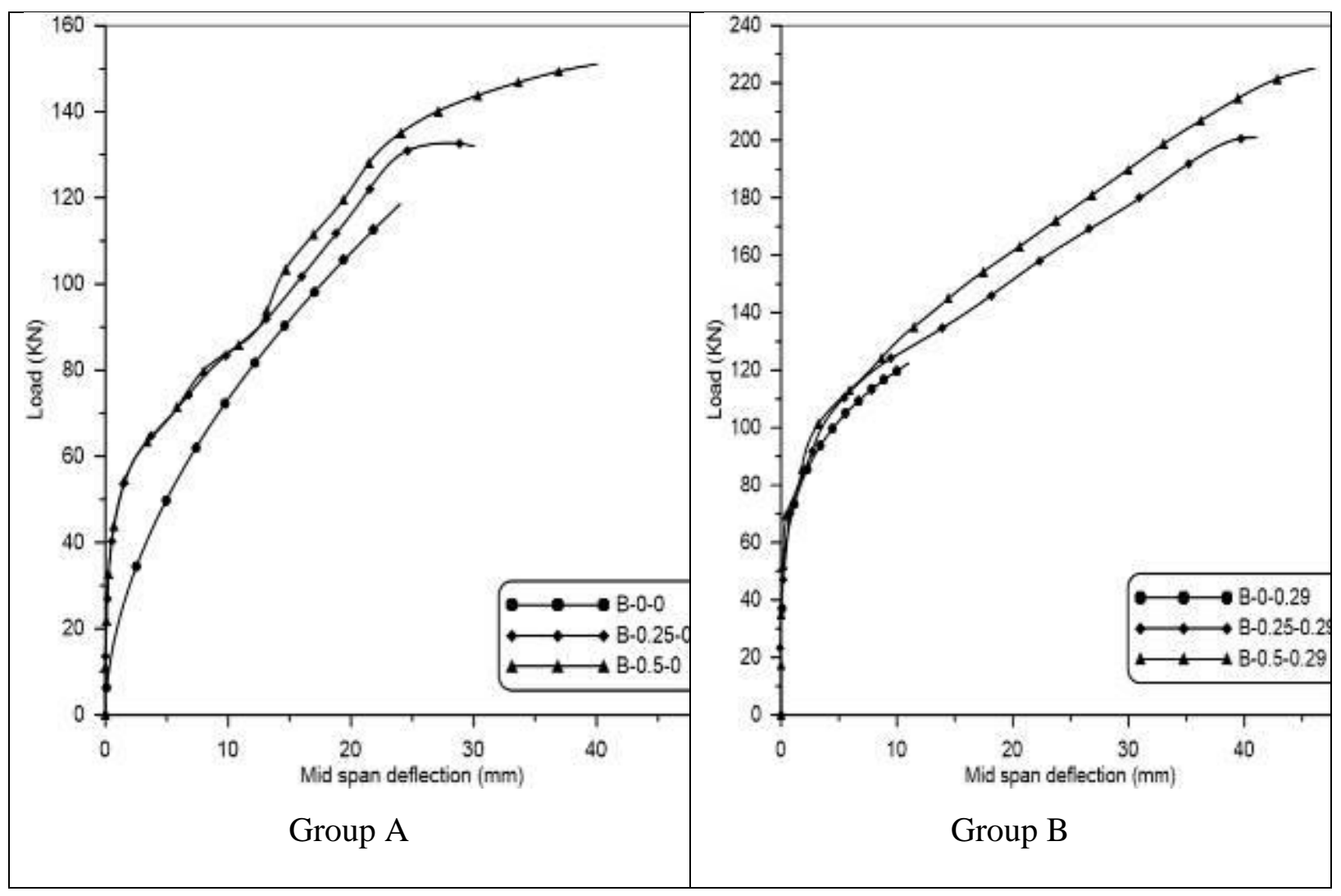




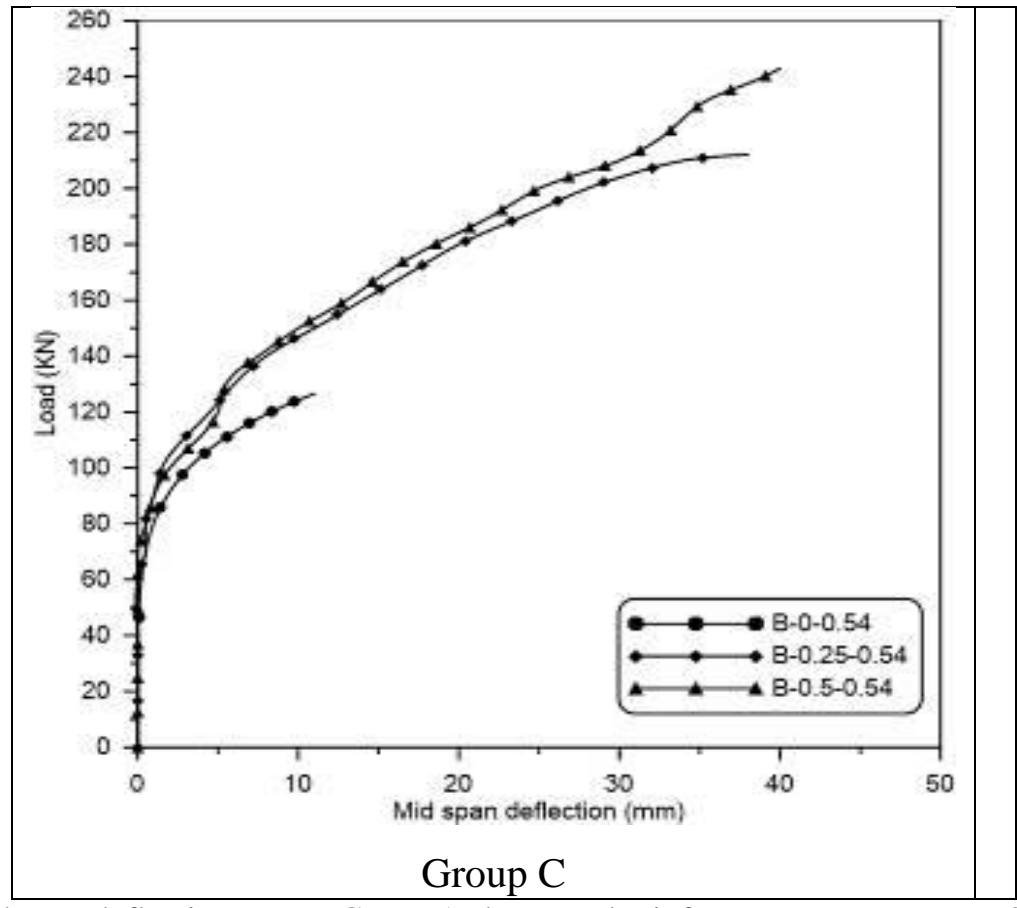

Fig (6) Load- mid span deflection curves Group A shear steel reinforcement percentage =0, Group B shear steel reinforcement percentage $=0.29$ and Group $\mathrm{C}$ shear reinforcement percentage $=0.54$.

\subsection{Crack Patterns.}

The maximum crack widths and failure types of tested concrete samples are illustrated in table (4). It is observed that there are different behaviors and failure modes. For Beam B-0-0 which neither contains shear steel reinforcement nor PVC fiber reinforcement, the failure mode is a pure shear failure that forms a single inclined crack for each shear span initiated in the middle shear span and parallel to the load support line. Fig. (7) shows the cracks formed during testing to the mentioned beam. In the cases of beams containing shear reinforcement, PVC fiber reinforcement or both, there is compatibility in crack appearance and progress and even the failure mode. Cracks were multiple and widely spread in both shear spans. At mid spans, vertical flexural cracks were formed, and diagonal shear cracks were formed after that starting from load point to the support with the appearance of many cracks at the region between the loading point and supports through the increasing values of loading to failure. Claiming observation that in the participation of PVC fiber reinforcement, the crack widths were reduced, their pointing was slower and the width between cracks was reduced.

Moreover, a remarkable difference was recorded when using the PVC fiber reinforcement (0.5) percentage combined with shear steel reinforcement (0.54) percentage in reinforced concrete beam intended B-0.5-0.54. The cracks in the middle of beam were more noticeable than the rest of the cracks. This led to other mode of failure of the bending as shown in Fig. (7). Here by adopting suitable PVC fiber reinforcement percentage and shear steel reinforcement causes greater shear strength with lower cracks width. .

\begin{tabular}{ccc||ccc}
\hline Beam define & $\begin{array}{c}\text { Maximum } \\
\text { crack width } \\
(\mathrm{mm})\end{array}$ & Failure type & Beam define & $\begin{array}{c}\text { Maximum } \\
\text { crack width } \\
(\mathrm{mm})\end{array}$ & Failure type \\
\hline B-0-0 & 3.01 & Shear & B-0.5-0.29 & 1.84 & Shear \\
B-0.25-0 & 2.45 & Shear & B-0-0.54 & 1.32 & Shear \\
B-0.5-0 & 2.17 & Shear & B-0.25-0.54 & 1.32 & Shear \\
B-0-0.29 & 2.1 & Shear & B-0.5-0.54 & 1.21 & Bending \\
B-0.25-0.29 & 1.65 & Shear & --- & ------ & -- \\
\hline
\end{tabular}

Table No. (4) shows the maximum crack width and failure types of concrete beams. 


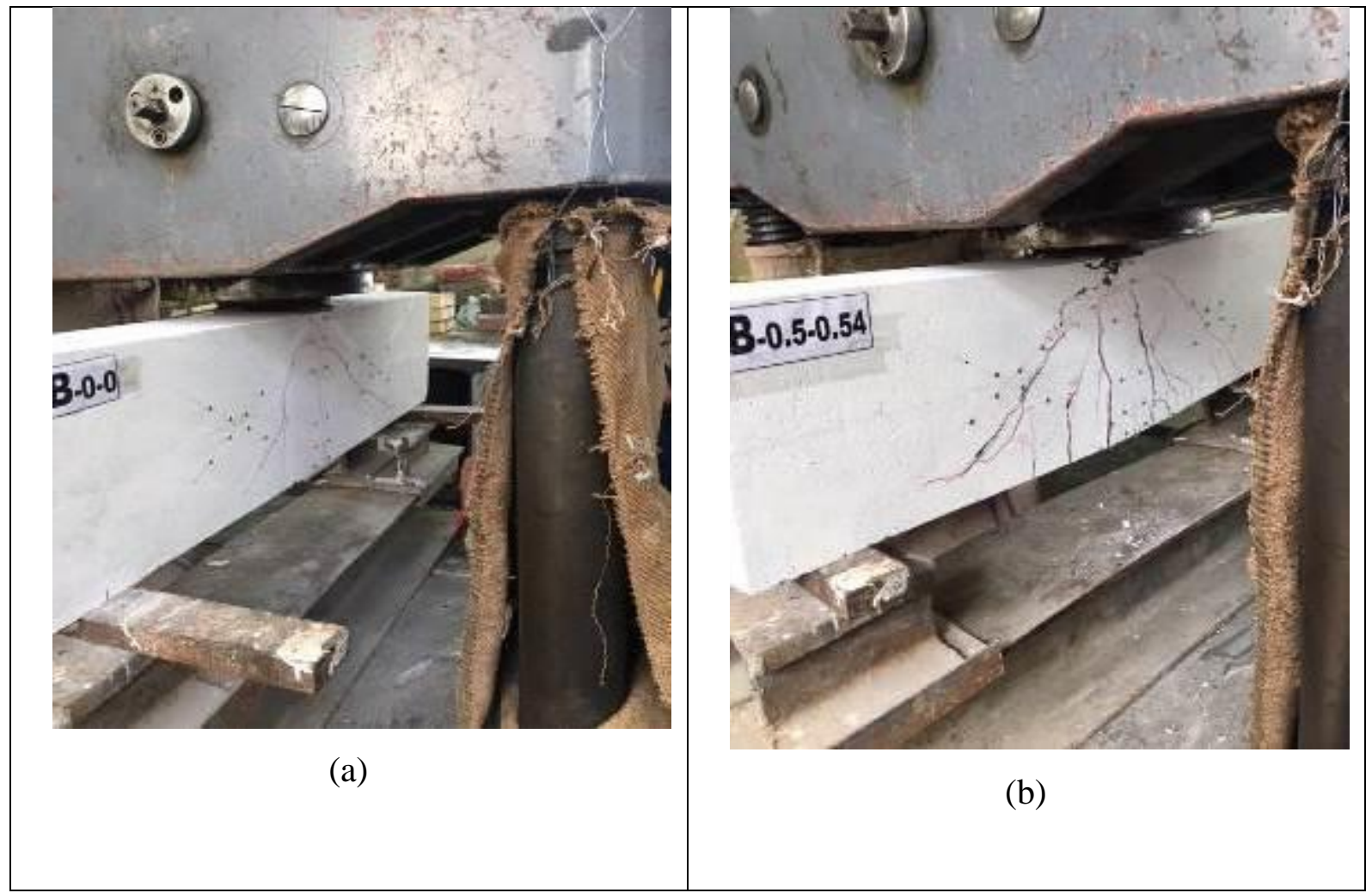

Fig. (7). Shows the cracks formed after testing of (a) B-0-0 and (b) B-05-0.54. 


\section{7- Conclusion:}

To consider the a non-corrosion material PVC fiber reinforcement as alternative material for shear steel reinforcement, nine concrete beams with different percentage of PVC fiber, shear reinforcement or combined both materials. Therefore, the conclusions could be summarized:

1- The cracking loads record a significant increase with availability and increasing the PVC fiber reinforcement of a concrete beam without or with shear steel reinforcement. The higher increasing percentage records $68.3 \%$ for beam contained PVC fiber reinforcement (0.5) compared to the same beam without PVC fiber reinforcement. 2-Using a specific ratio of PVC fiber reinforcement (0.25) for a concrete beam gives a different incremental ration in ultimate load compared to the other PVC fiber reinforcement ratios. 3- The ductility of concrete beam is increased with availability and increasing the PVC fiber reinforcement. Deflection at mid span is also decreased.

4- Adopting combined PVC fiber and shear steel reinforcement for concrete beams produces greater shear strength and lower crack width.

\section{8- Future Recommendation:}

Based on the results of this research study, the suggested recommendations for future work are the following:

1- Conduct a numerical model taking into accounts the PVC fiber distribution. That has to be combined with the experimental results that reinforced with PVC fiber and performing additional experimental work to reach the optimum PVC fiber distribution. 2-Study the effect new geometries and different lengths of PVC fibers reinforcement for reinforced concrete beams.

3- Investigate the behavior of reinforced concrete beams for service life such as fatigue and durability.

\section{References:}

[1]. Voo, Yen Lei, Wai Keat Poon, and Stephen J. Foster.,2010, "Shear strength of steel fiberreinforced ultrahigh-performance concrete beams without stirrups.",2010, Journal of structural engineering, 136.11, 1393-1400.

[2]. Cucchiara, Calogero, Lidia La Mendola, and Maurizio Papia.,2004, "Effectiveness of stirrups and steel fibres as shear reinforcement.",2004, Cement and concrete composites, 26.7, 777-786.

[3]. Grzybowski, Miroslaw, and Surendra P. Shah.,1990, "Shrinkage cracking of fiber reinforced concrete.",1990, Materials Journal, 87.2 , 138-148. [4]. Qi, Chengqing, Jason Weiss, and Jan Olek.,2003, "Characterization of plastic shrinkage cracking in fiber reinforced concrete using image analysis and a modified Weibull function.",2003, Materials and Structures, 36.6 , 386-395.

[5].Oh, B. Lim, D. Hong,K.Yoo ,1999,"Structural behavior of steel fiber reinforcement concrete beams in shear ." ,1999,Structural Journal,9-19.

[6]. Cucchiara, Calogero, Lidia La Mendola, and Maurizio Papia.,2004, "Effectiveness of stirrups and steel fibres as shear reinforcement.",2004, Cement and concrete composites, 26.7 ,777-786.

[7]. Daniel, de Lima Araújo, Feranda,Gabrielle and Romildo Dias Toledo.,2014, "Shear strength of steel fiber-reinforced concrete beams.",2014, Acta Scientiarum. Technology, 36.3 ,389-397.

[8]. Hasgul, Umut, et al.,2018, "Flexural behavior of ultra-high-performance fiber reinforced concrete beams with low and high reinforcement ratios.",2018, Structural Concrete, 19.6 , 1577-1590. [9]. Kahanji, Charles, Faris Ali, and Ali Nadjai.,2017, "Structural performance of ultrahigh-performance fiber-reinforced concrete beams."2017, Structural Concrete, 18.2 , 249-258.

[10]. Bazant, Z.P., and Yu, Q.,2005, "Designing against size effect on shear strength of reinforced concrete beams without stirrups".,2005,Journal of Structural Engineering, 131.11, 777-786.

[11]. Grzybowski, Miroslaw, and Surendra P. Shah.,1990, "Shrinkage cracking of fiber reinforced concrete.",1990, Materials Journal, 87.2 , 138-148. [12]. Banthia, N., M. Azzabi, and M. Pigeon. "Restrained shrinkage cracking in 405-413.

[13]. Yen, Lei, Voo,Stephen,J.,Foster and R.,Ian,Gilbert.,2006,"Shear strength of fiber reinforced reactive powder concrete prestressed girders without stirrups" ,2006,Junrnal Advanced Concrete Technology,4.1 , 123-132.

[14].Voo,J.P.,2004," An investigation into the behavior of prestressed reactive powder concrete girders subjects to non-flexural actions.", PHD Thesis, school of civil and Environmental Engineering, the University of New Wales,Sydney,Australia. 